\title{
SELF-HEALING BEHAVIOUR OF PRE-CRACKED POFA-CONCRETES IN DIFFERENT CURING CONDITIONS
}

\author{
K.A. Shahid*, M.F.M. Jaafar and F.M. Yahaya \\ Faculty of Civil Engineering \& Earth Resources, \\ Universiti Malaysia Pahang, \\ 26300 Gambang, Pahang, Malaysia \\ *Email: khairulanuars@ump.edu.my \\ Phone: +6095493373; Fax: +6095492998
}

\begin{abstract}
The investigation of the effect of curing conditions on self-healing of pre-cracked concrete containing palm oil fuel ash (POFA)-concrete is presented. Concrete grade 30 was used and POFA cement replaced $10 \%, 20 \%$ and $30 \%$ of the total weight of ordinary Portland cement [1].The compressive strength was tested after 7, 28, 60 and 90 days cured in water in order to investigate the strength development of the POFA-concretes. In addition, the pre-crack (hairline crack) concrete was examined under compression load to determine the effectiveness of self-healing POFA-concretes after different curing conditions. Four types of curing condition, namely air, room temperature, wet and dry, and water curing were tested. An ultra-pulse velocity (UPV) test was performed after 7, 28, 60 and 90 days of curing to monitor the self-healing progress in the POFA-concrete. The results show that POFA-concrete witha $20 \%$ replacement level recorded the highest compressive strength. It was also revealed that the UPV readings increased significantly with increased curing age. The results showed that the selfhealing ability of pre-cracked POFA-concrete at $10 \%$ replacement level increases significantly for the water curing condition. From these findings, the optimum POFA replacement level was recorded at $20 \%$ for the strength, while inclusion of a $10 \%$ POFA replacement level was appropriate for self-healing concrete.
\end{abstract}

Keywords: POFA-concretes; compressive strength; self-healing; curing condition; ultrapulse velocity.

\section{INTRODUCTION}

In Malaysia, with development of the agricultural-based industry it has become the largest producer focusing on the palm oil industry. Malaysia has become the current number one palm oil producer in Asia and developments will see it maintain its lead position over the next one and a half decades, producing 18 million tonnes or $42 \%$ of the world's palm oil in 2020 [2, 3]. It is predicted that the quantity of palm oil fuel ash (POFA), a profitless by-product generated by palm oil mills, will increase as the production of palm oil continues to grow over the years. Therefore, it is anticipated that success in discovering how to utilize this material in any type of material-making process would enable reduction of the quantity of waste and assist the palm oil industry to be a more ecologically friendly sector. Looking at the history of this material since its introduction intothe construction sector, it has been Malaysian researchers who have managed to prove that it possesses pozzolanic properties [4-8]. Abdul Awal and 
Hussin [9] have proved that this waste could be used as a partial cement replacement in concrete for the production of stronger and more durable construction material. Following these findings, more researchers have integrated POFA as one ingredient in the mix to produce a new type of concrete [10-13]. POFA is a by-product produced in palm oil mills. After palm oil is extracted from the palm oil fruit, both the palm oil husk and palm oil shell are burned as fuel in the palm oil mill's boiler. Generally, after combustion, about $5 \%$ of POFA solid wastes are produced $[12,14]$. In practice, POFA produced in Malaysian palm oil mills is dumped as waste without any profitable return. However, accelerated developments in concrete research over the past 20 years have opened up new and more proficient utilization of components available in nature, including industrial waste. In recent years, studies on using waste generated from agricultural and industrial activities as partial replacement of cement in concrete have been growing rapidly [15-18] Many researchers have studied the use of agrowaste ashes as constituents in concrete. The findings revealed that this agro-waste ash containsa high amount of silica in amorphous form and can be used as a pozzolanic material $[12,19,20]$. Previous researchers found that the pozzolanic activity indices of POFA at about $78.6 \%$ to 87.6\%, are much higherthanother classes of pozzolanic ash, at about 75\% (ASTM C 618-94a; Sumadi and Hussin [21]; Abdul Awal and Hussin [19]). According to Abdul Awal and Hussin [9], it is found that replacement with 30\% POFA can produce higher concrete strength and durability compared to normal concrete. As is known, concrete is widely used in building engineering, but in the early phase of concrete hardening, hairline creep usually occurs during the hydration process. Concrete containing high pozzolana such as palm oil fuel ash (POFA) was introduced as an alternative material to overcome this problem. In this study, the focus was on investigation of concrete containing POFA as a cement replacement. The effectiveness of using POFA in concrete as self-healing concrete under different curing periods and conditions is determined.

\section{EXPERIMENTAL SET-UP}

\section{Palm Oil Fuel Ash (POFA) Preparation}

In this study, palm oil fuel ash (POFA) was collected from the palm oil mill at Felda Lepar Hilir, Pahang. POFA was obtained after burning of the palm oil husk, fibre and palm kernel shell in the palm oil mill boilers. Before the POFA can be used as a cement replacement in concrete mix, the raw POFA is sieved using a sieve shaker. In this test, particle sizes passing $300 \mu \mathrm{m}$ were collected. Then, the POFA was ground in a Los Angeles abrasion test machine to produce fine particles like cement. During the process, 10 stainless steel bars with a diameter of $12 \mathrm{~mm}$ and length of $800 \mathrm{~mm}$ were used instead of steel balls to grind the POFA, as reported in Abu [4]. Figure 1 shows the particle analysis of POFA and OPC.

\section{Materials and Mix Proportion}

The cementitious materials used are ordinary Portland cement [1] and palm oil fuel ash (POFA). The chemical compositions of OPC and POFA are shown in Table 1. In this study, the control concrete mix was prepared using OPC, while the POFA-concretes were prepared by replacing cement with POFA at 10\%, 20\% and 30\% replacement levels. Coarse aggregate with a nominal size of $10 \mathrm{~mm}$ and fine aggregate passing 600 $\mu \mathrm{m}$ were used. All series of concrete were designed for grade 30. 


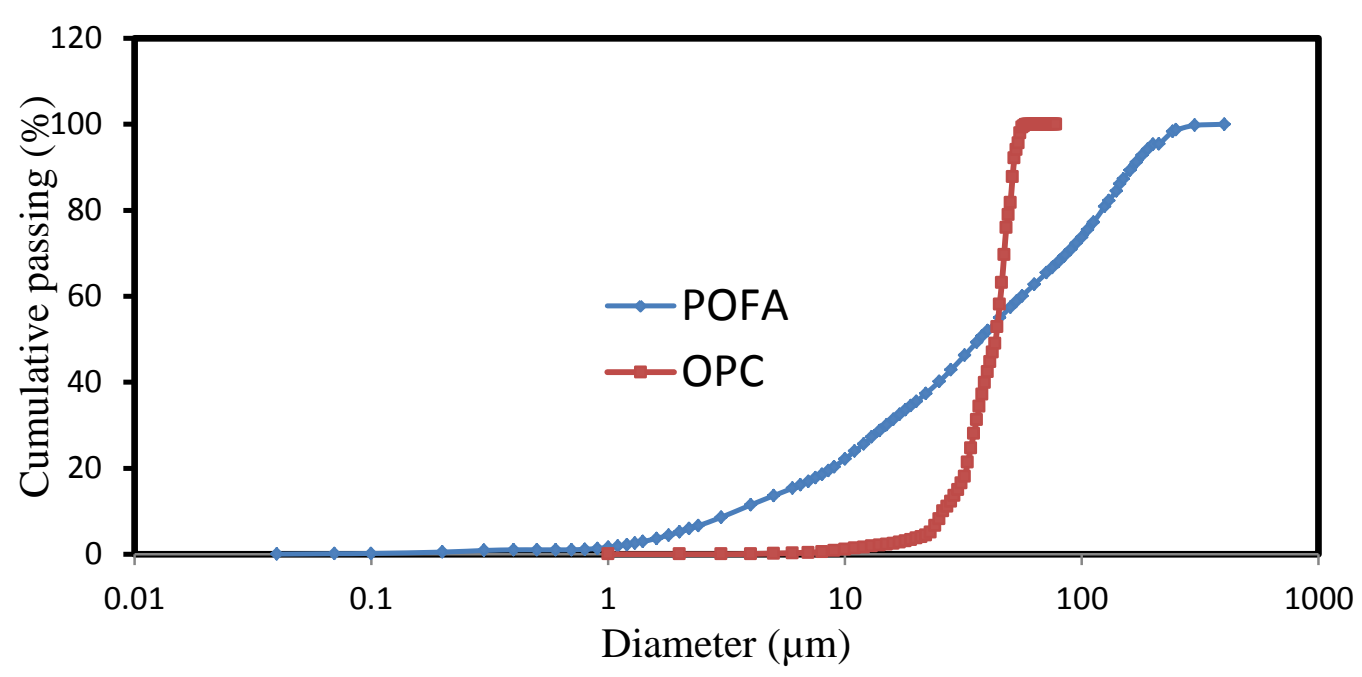

Figure 1. Particle analysis of POFA and OPC.

Table 1. Chemical composition of POFA and OPC.

\begin{tabular}{lcc}
\hline Chemical Composition & POFA & OPC \\
\hline Silica, $\mathrm{SiO}_{2}$ & 71.20 & 21.45 \\
Aluminium oxide, $\mathrm{Al}_{2} \mathrm{O}_{3}$ & 2.78 & 3.62 \\
Ferric oxide, $\mathrm{Fe}_{2} \mathrm{O}_{3}$ & 6.96 & 3.50 \\
Calcium oxide, $\mathrm{CaO}$ & 4.43 & 60.98 \\
Magnesium oxide, $\mathrm{MgO}$ & 1.18 & 0.59 \\
Sodium oxide, $\mathrm{Na}_{2} \mathrm{O}$ & 0.07 & 0.25 \\
Loss of ignition, $\mathrm{LOI}$ & 3.10 & 1.37 \\
\hline
\end{tabular}

\section{Experimental Procedures}

\section{Compressive Strength}

In order to determine the strength development of OPC-concrete and POFA-concretes, the compressive strength test was conducted after 7, 28, 60 and 90 days cured in water. Compressive strength was determined by using a $150 \mathrm{~mm}$ cube in accordance with BS 1881: Part 116 (1983). Compressive strength testing was conducted to determine the optimum percentage of POFA replacement used in concrete.

\section{Pre-Cracking Concrete}

Before the ultrasonic pulse velocity (UPV) test was performed, the remaining concrete specimens underwent four different types of curing: water curing, air curing, wet and dry curing and control room curing. For the wet and dry conditions, the specimens were subjected to natural environment to complete the cycle. Meanwhile, the specimens were maintained at a room temperature of $20^{\circ} \mathrm{C}$ and $65 \%$ RH. Figure 2 shows the specimens under different types of curing. All the specimens were cured for 7 days for the early hydration process, then taken out from the curing process to measure the initial readings using UPV. The standard UPV classifications are in accordance with EN 12504-4: 2004. 


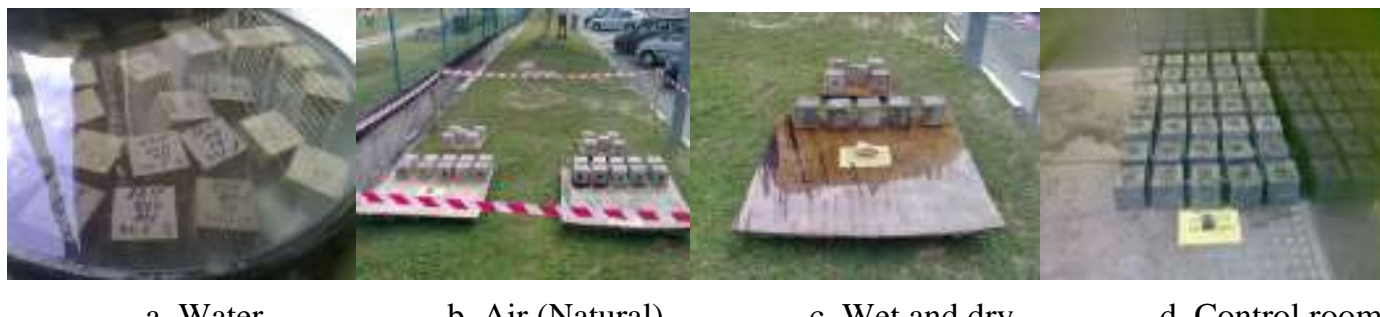

Figure 2. Types of curing condition.

In order to monitor the progress of the self-healing concrete activity, the specimens were subjected to compression load to induce hairline cracks (pre-cracking). In this study, load ranges between $400 \mathrm{kNand} 480 \mathrm{kN}$ were applied with a nominal loading rate of $0.2 \mathrm{kN} / \mathrm{mm}^{2} \mathrm{~s}$. Then, the hairline cracks were measured using a digital caliper under a microscope to measure the hairline widths in ranges of $0.1 \mathrm{~mm}$ to 0.2 $\mathrm{mm}$. Figure 3 shows the method of measuring the width of the cracks. After precracking of the concrete using compression machines, the UPV readings were taken as shown in Figure 4. Then, all the specimens continued to be cured in the four different types of curing conditions for periods from 28 days up to 90 days. After completion of each cycle, specimens were taken out and UPV readings were taken to monitor the progress of the self-healing concrete.
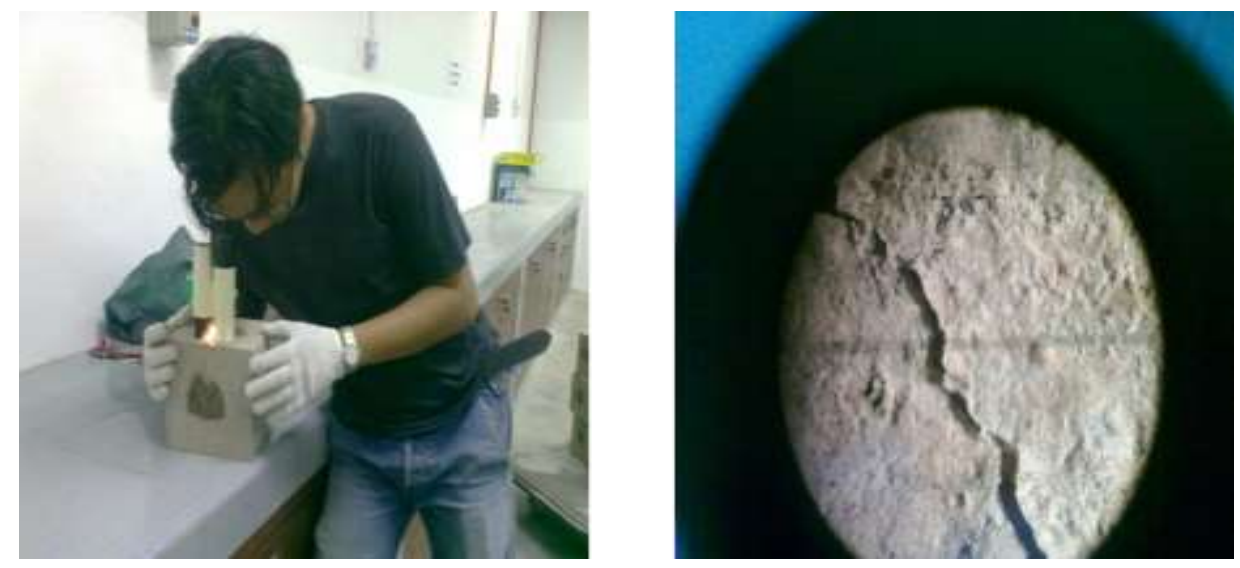

Figure 3. Pre-cracked hairline measurement on concrete specimen under microscope.

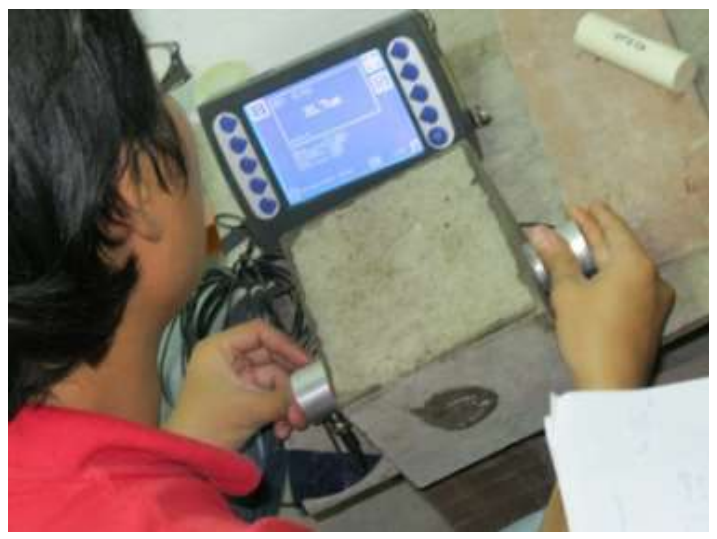

Figure 4. UPV measurement of concrete specimen. 


\section{RESULTS AND DISCUSSION}

\section{Properties of Palm Oil Fuel Ash}

The chemical composition of palm oil fuel ash (POFA) was tabulated earlier in Table 1. It is shown that the silica content $\left(\mathrm{SiO}_{2}\right)$ in POFA is much higher than in ordinary Portland cement [1]. The presence of a higher amount of $\mathrm{SiO}_{2}$ would assist the pozzolanic reaction. However, the calcium oxide $(\mathrm{CaO})$ is lower than in OPC, while the LOI value of POFA is higher than OPC, at $3.10 \%$. From the chemical analysis, it is revealed that POFA is a satisfactory pozzolanic material and may be used as a cement replacement. In addition, a particle size analysis to determine the size distribution of POFA was conducted in this study. As displayed earlier in Figure 1, the particle size distribution of POFA is within the range of the OPC. It is noted that the particle sizes of cement are between $0.04 \mu \mathrm{m}$ and $100 \mu \mathrm{m}$, while in POFA they are between $1 \mu \mathrm{m}$ and $80 \mu \mathrm{m}$. Therefore, it can be stated that this POFA can be used as a microfiller to replace conventional cement used in concrete.

\section{Effect on Compressive Strength}

Generally, the use of POFA in concrete as a cement replacement can improve the concrete strength. The results forthe compressive strength of the OPC-concretes and POFA-concretes are shown in Figure 5. It is revealed that POFA enhances the strength of concrete after 28 days immersed in water. The early strength of the POFA-concretes decreases with the increasing amount of POFA. After 7 days of curing, the $10 \%$ replacement shows a very marginal increase in strength compared to theother POFAconcretes. However, the strength slightly increases at the $20 \%$ and $30 \%$ replacement levels after the specimens have matured for 28 days, but the strength is still lower than the control specimens. At an early age, it is found that POFA shows negative strength development compared to OPC concrete due to an improper dilution effect. The POFA cement does not blend well.

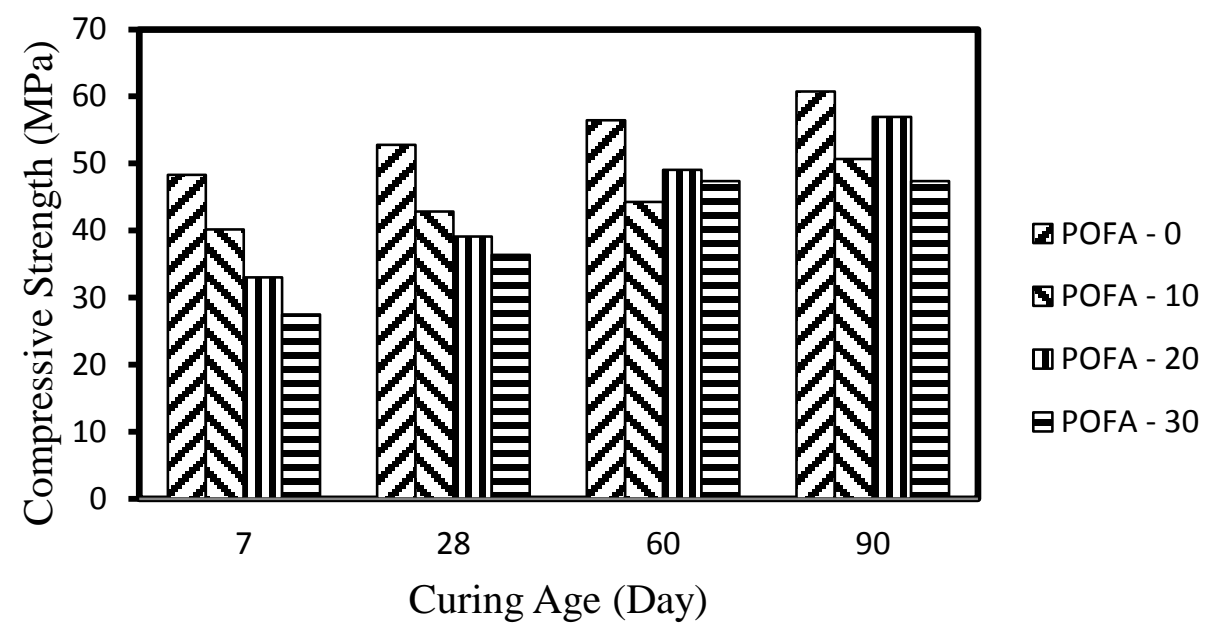

Figure 5. Compressive strength of OPC-concrete and POFA-concretes.

It is also found that the compressive strength of POFA-concrete with $20 \%$ replacement increases rapidly compared to the other POFA-concretes. This happens 
because the addition of $20 \%$ POFA is suitable as a cement replacement due to the microfiller effect of the POFA size. After 28 days of hardening, POFA acted as a microfiller and then accelerated the hydration of cement and finally led to a pozzolanic reaction. It is also shown that the compressive strength reduced at higher levels of replacement. This is because the high pozzolana content in POFA-concrete reduces the strength. The same behaviour was observed by Abdul Awal and Hussin [9], who discovered that the addition of POFA in concrete will improve its strength. In addition, Massazza [22]found that higher replacement of POFA in concrete may lead to a decrease in concrete strength. Therefore, it is found that the optimum POFA replacement in concrete is $20 \%$.

\section{Effect of Curing on Self-Healing of Pre-Cracked POFA-Concrete}

Assessment of self-healing development for pre-cracked concrete was conducted using ultrasonic pulse velocity (UPV) after the specimens were exposed for 7 (pre-crack), 28, 60 and 90 days. The UPV results for POFA-concretes exposed to air curing are shown in Figure 6. After pre-cracking of the specimens at day7, the progress of self-healing in POFA-concretes for all mixes increased significantly with the increase of curing age. It is shown that POFA cement at $10 \%$ and $30 \%$ replacement levels develops about $2.77 \%$ and $6.80 \%$ respectively after 28 days. This is because POFA is able to self-seal the cracks inside the concrete. On the other hand, Figure 7 displays the results of UPV readings for POFA-concrete cured at room temperature. It is clearly shown that the selfhealing of POFA-concrete increases significantly compared to the control concrete. Concrete at $10 \%$ and $30 \%$ replacement level shows the highest UPV values compared to the other POFA-concretes. However, it can be stated that the self-healing ability of POFA-concrete increased with the increase of curing age and the optimum mix amount is $10 \%$.

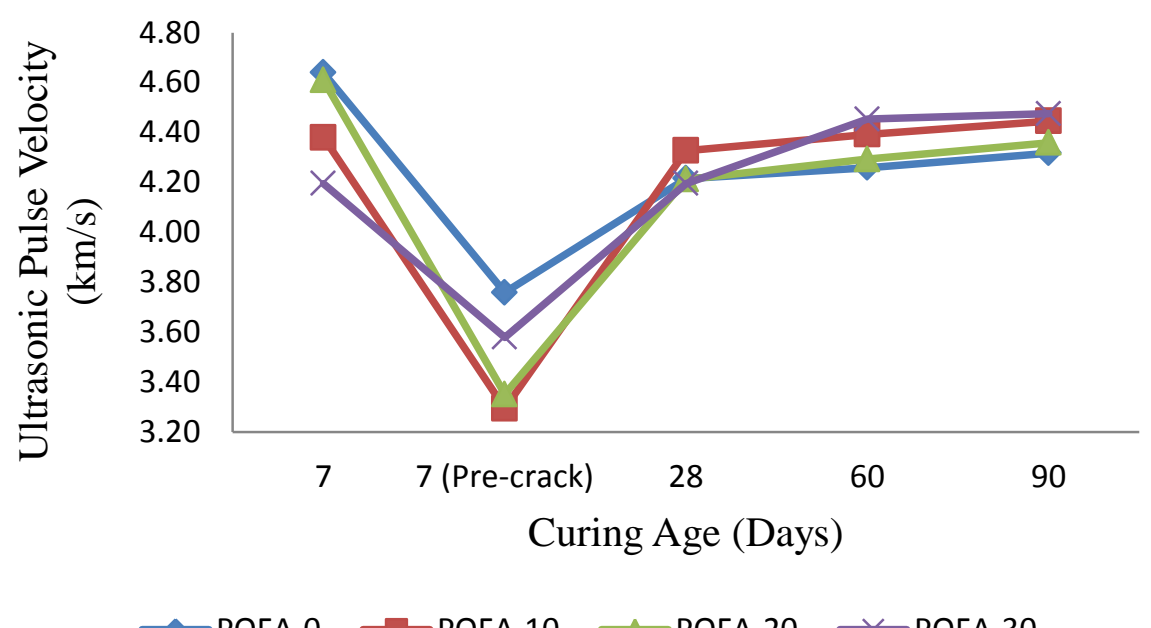

Figure 6. UPV readings for POFA-concretes in air curing condition.

The UPV readings on self-healing POFA-concrete for specimens exposed to the wet and dry condition are illustrated in Figure 8 . The results indicate that after precracking of the concrete, the control concrete and POFA-concrete at $10 \%$ and $20 \%$ replacement levels show that the self-healing ability of concrete increased rapidly. 
However, the self-sealing for control concrete is still lower than the POFA-concretes. It is suggested that POFA at $10 \%$ and $20 \%$ replacement level obtain yields the optimum percentage for the dry and wet condition. However, it was found that when the specimens were cured for 28 day, the speed of hydration of the 30\% POFA becomes faster. The results obtained on the progress of self-healing for concrete subjected to water curing are shown in Figure 9. It is clearly shown that the UPV readings for all POFA-concretes developed significantly compared to the control concrete. The selfhealing ability of POFA-concrete increased with the decrease of the amount of POFA. When the mixing amount of POFA is $10 \%$ replacement, the self-healing ability of concrete is the strongest.

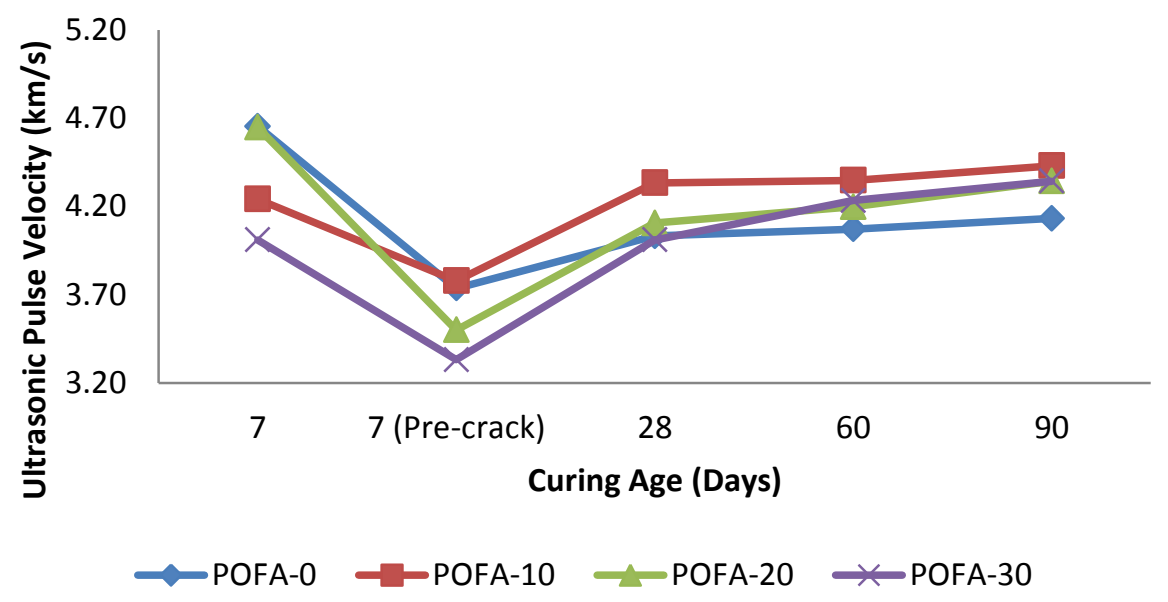

Figure 7. UPV readings for POFA-concretes in room temperature condition.

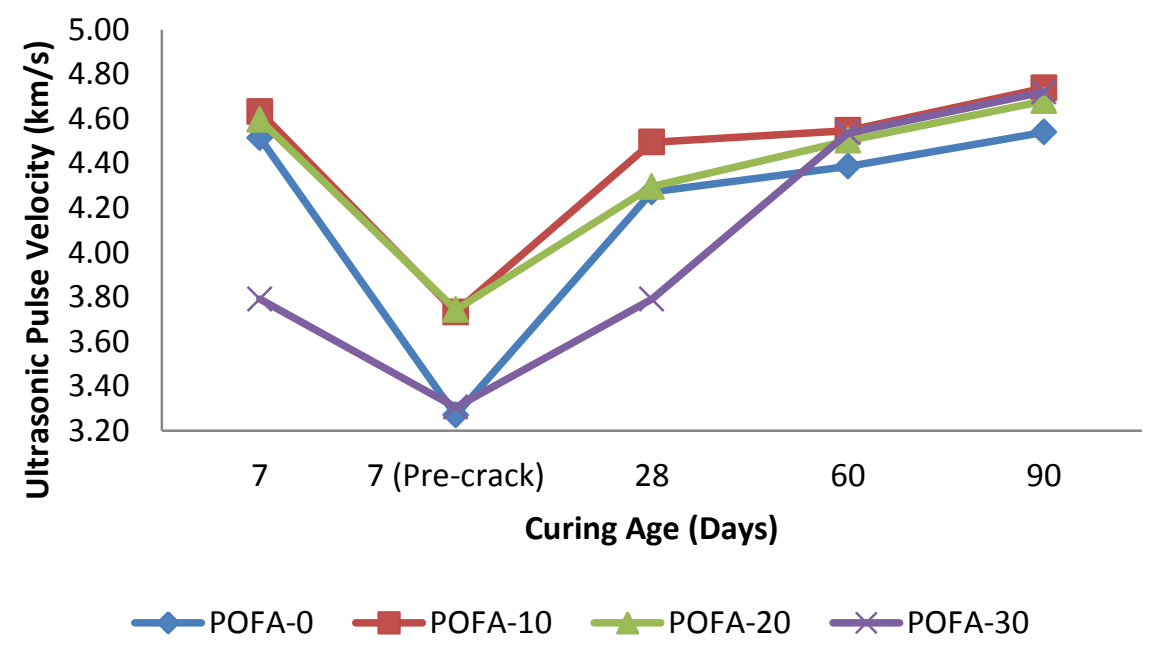

Figure 8. UPV readings for POFA-concretes in dry and wet condition.

In summary, the relationship between the mixing amount of POFA and the selfhealing ability of concrete under different curing conditions is clearly presented. The self-healing progress was measured by the increase of the self-sealing effect recorded by UPV before and after self-healing. It is found that in the early stage, the degree of hydration of POFA is small and is mainly affected by the curing condition. In the late stage, POFA hydrated to produce $\mathrm{C}-\mathrm{S}-\mathrm{H}$ gel and the self-healing of concrete increased. 
All the POFA mixes have the best conformance, and the self-healing ability is best represented by the changes of concrete specimens before and after pre-cracking. It is found that when the mixing amount of POFA is $10 \%$ subjected to the water curing condition, the self-healing ability of the concrete is much stronger than the other concrete mixes under different curing conditions.

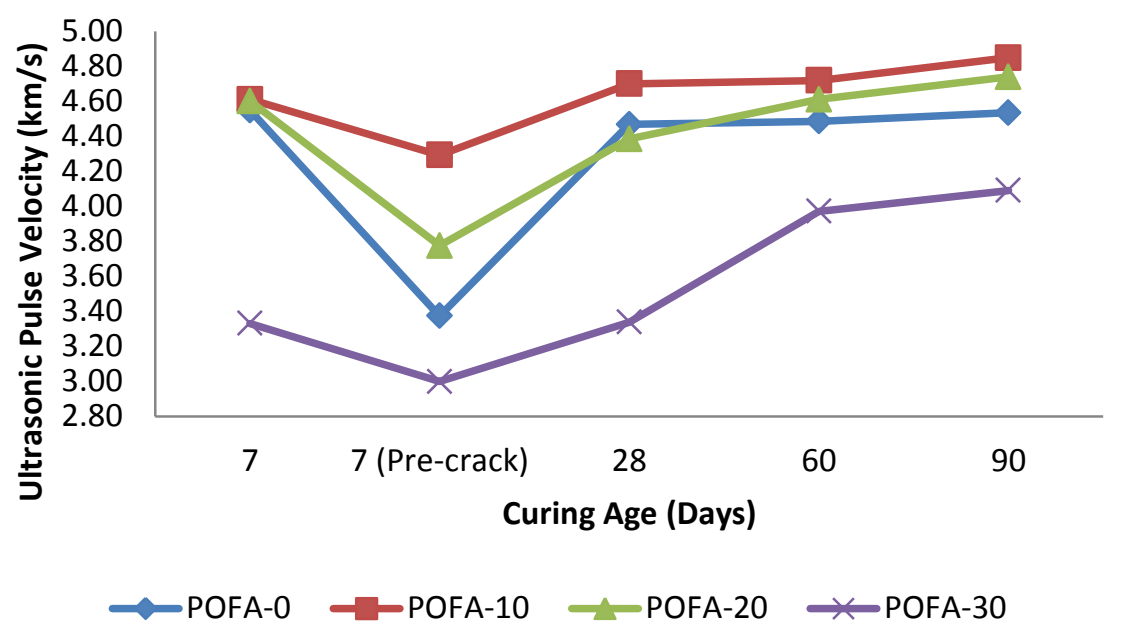

Figure 9.UPV readings for POFA-concretes in water condition.

\section{CONCLUSIONS}

Based on the observations, the following conclusions can be drawn:

1. Using POFA in concrete as cement replacement improves significantly the compressive strength. The use of POFA at $20 \%$ replacement level in concrete recorded the highest compressive strength.

2. The UPV readings increase significantly with the increase of curing ages for all curing conditions. It is proved that the progress of self-sealing of pre-cracked POFA-concretes is affected by the different curing conditions.

3. It is proved thatthe self-healing ability of pre-cracked POFA-concrete at the $10 \%$ replacement level increases significantly under the water curing condition.

\section{REFERENCES}

[1] Usta N, Öztürk E, Can Ö, Conkur E, Nas S, Con A, et al. Combustion of biodiesel fuel produced from hazelnut soapstock/waste sunflower oil mixture in a diesel engine. Energy Conversion and Management. 2005;46:741-55.

[2] Basiron Y, Simeh MA. Vision 2020-the palm oil phenomenon. Oil Palm Industry Economic Journal. 2005;5:1-10.

[3] Ismail MA, Budiea A, Hussin M, Muthusamy KB. Effect of POFA fineness on durability of high strength concrete. Indian concrete journal. 2010;84:21-8.

[4] Abu Z. The pozzolanicity of some agricultural fly ash and their use in cement mortar and concrete 1990.

[5] Awal A, Nguong SK. A Short-Term Investigation on High Volume Palm Oil Fuel Ash (POFA) Concrete. Proceedings of the 35th Conferenece on our World in Concrete and Structure. 2010:185-92. 
[6] Abdullah K, Nasly M, Hussin MW, Nordin N, Zakaria Z. Properties of aerated concrete containing various amount of palm oil fuel ash, water content and binder sand ratio. 2nd International Conference on Chemical, Biological and Environmental Engineering. 2010, p. 391-5.

[7] Safiuddin M, Abdus Salam M, Jumaat MZ. Utilization of palm oil fuel ash in concrete: a review. Journal of Civil Engineering and Management. 2011;17:23447.

[8] Bamaga S, Hussin M, Ismail MA. Palm Oil Fuel Ash: Promising supplementary cementing materials. KSCE Journal of Civil Engineering. 2013;17:1708-13.

[9] Abdul Awal A, Hussin M. Some aspects of durability performances of concrete incorporating palm oil fuel ash. Proceedings of the 5th International Conference on Structural Failure Durability and Retrofitting1997. p. 210-7.

[10] Mat Yahaya F. Pengaruh abu terbang kelapa sawit terhadap kekuatan mampatan dan ketahanlasakan konkrit berudara: Universiti Teknologi Malaysia; 2003.

[11] Sata V, Jaturapitakkul C, Kiattikomol K. Utilization of palm oil fuel ash in highstrength concrete. Journal of Materials in Civil Engineering. 2004;16:623-8.

[12] Tangchirapat W, Saeting T, Jaturapitakkul C, Kiattikomol K, Siripanichgorn A. Use of waste ash from palm oil industry in concrete. Waste Management. 2007;27:81-8.

[13] Deepak T, Elsayed A, Hassan N, Chakravarthy N, Tong SY, Mithun B. Investigation on Properties of Concrete with Palm Oil Fuel Ash as Cement Replacement. International Journal of Scientific \& Technology Research. 2014;3:138-42.

[14] Abdullah K, Warid AH. POFA: a potential partial cement replacement material in aerated concrete. 6th Asia-Pacific Structural Engineering and Construction Conference. Kuala Lumpur, Malaysia; 2006.

[15] Tay J-H, Show K-Y. Use of ash derived from oil-palm waste incineration as a cement replacement material. Resources, conservation and recycling. 1995;13:27-36.

[16] Altwair NM, Johari MAM, Hashim SFS. Strength Activity Index and Microstructural Characteristics of Treated Palm Oil Fuel Ash. International Journal of Civil \& Environmental Engineering. 2011;11:100-7.

[17] Karim M, Zain M, Jamil M, Lai F. Significance of waste materials in sustainable concrete and sustainable development. International Conference on Biotechnology and Environment Management. 2011, p. 18-22.

[18] Hilton Ahmad M, Mohd Noor N. Chemical attack of Malaysian pozzolans concrete. Journal of Science and Technology. 2009;1:11-24.

[19] Awal AA, Hussin MW. Influence of palm oil fuel ash in reducing heat of hydration of concrete. Journal of Civil Engineering (IEB). 2010;38:153-7.

[20] Sooraj V. Effect of palm oil fuel ash (POFA) on strength properties of concrete. International Journal of Scientific and Research Publications. 2013;3:691.

[21] Sumadi S, Hussin M. Agricultural Ash (AA) Construction material for the future. Kongres Sains \& Teknologi Malaysia. 1993;1:105-14.

[22] Massazza F. Pozzolanic cement. Cements and Concrete Composites. 1993;15:185-214. 